\title{
CEO Growth Mindset In Re-Strategizing Logistic Management Practice During Pandemic
}

\author{
Agus Triyani ${ }^{1}$ dan Ratih Pratiwi ${ }^{2}$ \\ ${ }^{1}$ Jurusan Akuntansi Universitas Wahid Hasyim \\ ${ }^{2}$ Jurusan Manajemen Universitas Wahid Hasyim \\ Email : agustriyani@unwahas.ac.id
}

\begin{abstract}
Abstrak
Penelitian ini bertujuan untuk meneliti pengaruh kepemimpinan logistic dan kemampuan digitalnya terhadap kinerja manajemen logistic di Indonesia. Populasi dalam penelitian ini adalah pelaku shippning cargo industries. Pengambilan sample dalam penelitian ini menggunakan tehnik sensus, sejumlah 75 cabang PT Indah Logistic di Indonesia. Data diperoleh dari penyebaran kuesioner dengan measurements skala likert 1-5. Data tersebut kemudian dikumpulkan dan dianalisis menggunakan SEM PLS. Hasil penelitian menunjukkan bahwa semakin baik implementasi logistic leadership akan semakin meningkatkan kinerja manajemen logistic. Semakin CEO memiliki kapabilitas digital yang baik maka akan semakin mempengaruhi peningkatan kinerja manajemen logistic. Growth mindset memiliki pengaruh menguatkan logistic leadership dalam meningkatkan kinerja manajemen logistic.
\end{abstract}

Kata Kunci: Logistic Management, Logistic Cargo, Logistic Leadership, Digital Capability Growth mindset

\section{INTRODUCTION}

The development of integrated logistics transportation is an inseparable part of the logistics system for entrepreneurs who produce goods. Developed countries have more effective and efficient logistic transportation systems. Indonesia's logistic transportation sector still relies on a truck fleet of almost $90 \%$ of the total freight transport. This condition is exacerbated by violations of the overload threshold. The reason that land transportation still dominates the delivery of goods is due to the high cost of transportation by sea and air (Saragih, Hartati, and Fauzi 2020).

Logistics shipping costs by air in Indonesia are one of the most expensive in Southeast Asia (Yarlina 2013). Infrastructure development to support the logistics system has been carried out in Indonesia but has not been optimally utilized because it has not been directly integrated with industrial centers (Saragih, Hartati, and Fauzi 2020). Transportation improvement is a big mandate for superior Indonesia. It needs a strategic plan to increase the value of investment so that transportation facilities and infrastructure become competitive. Infrastructure development makes the effectiveness of transportation services better because it makes distance, time, travel speed, ease of transaction, level of safety, and security more efficient (Lambert, D., Stock, J. R., \& Ellram 1998).

There are three most widely used modes of transportation. The road transportation or trucking dominates the volume of goods transport by about 91 percent, sea transportation about 7.5 percent, and rail transportation around 1 percent. The imbalance of roles between modes is also reflected in the contribution of each mode to the Gross Domestic Product (GDP). From around Rp. 666.15 trillion GDP in the transportation sector in 2018, the land transportation mode (road) contributed 53.16\%; air transportation 36.1\%; sea transportation 6.7\%; river, lake, and ferry transportation (SDP) 2.417\%; and real transportation 1.577\%. Although land transportation contributes the highest, the highest growth rate in 2019 was in air transportation with 17.37 percent and rail transportation with 17.11 percent (supplychainindonesia.com2019).

The pandemic is a very long adventure, the plague practically stops mobility and forces people to stay at home or many call it "the death of mobility". The COVID-19 crisis brought humans back to ancient times where their life was only in caves, namely homes. The coronavirus (Covid-19) pandemic is one of the most impactful events of the $21^{\text {st }}$ century. Even at an early stage, the impact on tourism was enormous. Current estimates see 75 million tourism jobs at immediate risk and the industry losing more than US\$ 2.1 trillion in turnover (WTTC, 2020). Borders are closed, cruise ships are anchored, the entire air fleet is grounded, and hotels, restaurants, and tourist 
attractions are closed. The coronavirus pandemic is a disaster that physically affects the system as a whole and threatens its existence.

Besides the tourism sector which was also shaken, the travel sector also felt the impact. There were 8,198 people or $12.9 \%$ who were laid off in this sector due to a lack of income during the pandemic. Also, social restrictions in several areas have made it more difficult for startup businesses to maintain their business. Based on data Monday (8/6), the number of employees who were laid off in the transportation sector was 13.381 people or $21 \%$ of the 63.714 people who had been laid off (supplychainindonesia.com2019).

The Ministry of Transportation implements a special mechanism for air transportation with the enactment of the Minister of Transportation Regulation Number PM 18 of 2020 concerning the Determination of Public Health Emergencies for Corona Virus Disease 2019 (Covid-19). Air transportation providers will implement special mechanisms to prevent the spread of Covid-19. The rapid growth of the air transport service industry has made the national aviation business climate more conducive and competitive so that air transportation is increasingly needed to transport passengers and goods (cargo). Cargo transportation in Indonesia is still mixed with passenger transport using the remaining luggage capacity on the plane. The lack of aviation that has a dedicated air cargo transportation fleet still opens wide opportunities for cargo business in Indonesia (Yarlina 2013). The Covid-19 pandemic forces the government to create regulations that require people to stay at home. Employees are asked to work from home so telecommuting becomes a necessity for coordination. Air transportation operations also experience the same problem, with limited human resources, they still have to serve the logistical cycle so that shipments remain smooth (Chen and Chen 2020).

This article focuses on the change in the mindset of leaders in businesses that are highly dependent on the logistics of post-pandemic air transport operations, seizing opportunities, and breaking down barriers that occur in the digital era. Human resources are considered an important and valuable asset of an organization that is difficult to imitate and creates a sustainable competitive advantage by using innovative ideas (Tan et al. 2015). Human resources need to be motivated and need people to be able to manage these human resources effectively and efficiently(Rauter et al. 2019).

The role of the leader is very important in helping to maintain a quality workforce in the organization (Safonov Yu. M. 2017). Many studies have examined the role of leadership in the industry but not leadership styles that can act as mentors, guides, coaches, and stimulators to increase the vision of followers who are expected to be able to balance, improve and revive the logistics industry in Indonesia.

Logistics development is characterized by significant spatial diversity on a global scale such as Europe and the US, which have a high level of logistics development, and regions and countries where logistics practices are very low. This difference results from the level of economic development of countries and regions, which translates into the intensity of international exchanges and the need to use advanced information technology used in logistics solutions (Darkow, Foerster, and Von Der Gracht 2015). Digital capabilities greatly influence management practices in the digitalization era like today. Human resources who can use digital devices will make it easier for organizations to implement digital management (Nwankpa and Roumani 2016).

National and regional logistics diversification is also rooted in the degree of transportation infrastructure development and its adaptation to the needs of the economy in the field of moving goods for domestic export and import needs. Logistics also depends on the structure of the economy and the development of the industrial and service sectors, which affects the specificity of the supply chain (Sadowski, Wąsowska, and Nowak 2020). Although phenomena such as corporate globalization and internationalization are increasingly showing the rapid demand for cargo shipping by air, there are still gaps in post-pandemic air transport operations management.

\section{Logistics and Logistics Management}

Logistics is the science or art of storing, distributing, maintaining, and deleting certain goods or tools (Sadowski, Wąsowska, and Nowak 2020). Logistics is a series of planning, implementation, and monitoring of the process of moving, whether goods/services, energy, or other resources, from the starting point to the destination point. Logistics is the integration of 
procurement, transportation, inventory management, and warehousing activities in providing costeffective means to meet customer needs, both internal and external (Hamdam 2020). Logistics is a process that strategically manages the procurement, movement, and storage of materials, spare parts and finished goods along with the flow of related information through the organization and its marketing channels, in a way in which company profits, both current and future, can be maximized. by way of cost-effective order fulfillment (Griffin 2020).

Logistics activities aim to ensure the availability of the right goods at the right time and place by carrying out a series of logistical activities (C. Rutner and Langley 2006), namely: the process of procurement, production activities (manufacturing support), and distribution (physical distribution). The implementation of logistics activities has performance standards that must be achieved. The effectiveness of logistics activities is when there is a balance between the quality of service expected by customers with all costs incurred to achieve company goals. Two main factors to determine the level of logistics performance are the service, namely the level of company service to consumers, and the cost factor, namely the costs spent by the company to handle services to consumers.

Logistics Management is one of the important components in Supply Chain Management which is used to meet customer demand through planning, implementing, and controlling the efficiency and effectiveness of the flow and storage of goods, services, and related information from the starting to the destination point (Bowersox 2000). Logistics Management helps companies to reduce costs and improve their services to customers. Logistics Management aims to obtain and distribute materials and products at the right time, place, and quantity at the most efficient cost (Pujawan 2005). Management which involves order processing, warehousing, material/product handling, packaging, and transportation is also a sector that is growing rapidly in today's business world (Rutner \& Langley, 2000). Without the support of good Logistics Management, Production, and Marketing activities will be very difficult to carry out (Pujawan 2005).

Logistics Management is the responsibility of creating and managing systems to handle the flow of raw materials and finished goods (Mentzer, Stank, and Esper 2008). Logistics management is a series of planning, monitoring and organizing activities for procurement, distribution, recording, storage, maintenance and elimination of logistics to support effectiveness and efficiency in achieving organizational goals (Pujawan 2005). Logistics Management is a company activity related to location, facilities, transportation, inventory, communication, management, and storage (Bowersox, D. J., \& Daugherty 1995).

\section{Digital Capability}

Competencies possessed by digital workers have the digital fluency needed to utilize technology to manage data (Bowersox and Daugherty 1992), to represent information creatively, solve problems, and design new products and ways of working and can affect job performance and career development in various professions (Pratiwi et al. 2020). Digital Capability is the use of technology to find, use, and disseminate information in the digital world (Cenamor, Parida, and Wincent 2019). Digital Capability is defined as the ability to understand, analyze, assess, organize, and evaluate information received by utilizing digital technology (Balsmeier and Woerter 2019). In conclusion, Digital Capability is the ability to take advantage of various technologies and understand how to use them and to have an awareness of their impact on individuals and society. Digital Capability empowers individuals to communicate with others, work more effectively, and increase one's productivity, especially with people who have the same skills and ability levels. Technologies will develop alongside the time. Digital Capability is measured by several indicators, namely: 1) information and data literacy, 2) communication and collaboration, 3) digital content creation, 4) safety and 5) problem solving (Manilla et.al, 2019). The digital capability allows an organization to be able to increase the efficiency of time and distance by using technology. The individual's ability to operate digital technology will greatly assist the technology-mediated communication process, thereby increasing performance effectiveness and efficiency (Ul-Hameed et al. 2019). Sophisticated measurement systems are required to guide and control increasingly complex logistics systems. To achieve logistical excellence, companies must monitor their internal 
performance in five categories: costs; asset management; customer service; productivity; and quality (Bowersox and Daugherty 1992).

H1 : Digital capability has the potential to improve logistic management performance

\section{Logistic Leadership}

Leadership is the main way to get work done through other people and also by directing and guiding the behavior of people in a particular work environment (Ruben 2019). Leadership is an approach that can change the values of others and bring followers to achieve organizational goals (Bass 1985). Companies that are highly dependent on logistics transportation are those that focus on the integration of the process, which concerns the integration of overall asset commitments from purchases to physical distribution and operational decisions (Mena, C., Christopher, M., \& Van Hoek 2014). The policies taken in implementing the logistics business are closely related to customer service satisfaction and reflect industry standards (Quick and Nelson 2008).

The logistics leader's competence is utilized to provide adequate differentiation to ensure that the company gains and maintains a competitive advantage (Bowersox and Daugherty 1992). The logistics business is required to be sensitive to customer needs and view logistics competence as a competitive resource (Mogaka and Arani 2020). Leaders must produce a variety of value-added services, aimed at satisfying customers consistently. The business behavior and practices of logistic business leaders have an understanding and appreciation of the organizational structure and strategic orientation which can be used as guidelines for developing competitiveness (Ahmad and Ghayyur 2014).

Logistics leadership focuses on three core issues, namely formalization, flexibility, and measurement (Bowersox and Daugherty 1992). Formalization involves establishing rules and procedures to guide routine logistical operations and facilitate day-to-day decision making. Formal organizations tend to have more efficient performance (Quick and Nelson 2008). Very formal organizations have been characterized as less innovative and adaptive than organizations that are less formally organized. The formality shows how manageable functions are much more important than how many functions that can be managed by a company's logistics department but are not well managed. The assignments and functional relationships that are formally determined in leading companies are very dynamic as indicated by the reconfiguration, adjustment, and organizational restructuring (Bowersox and Daugherty 1992). Flexibility involves a framework to accommodate special situations that offer unique opportunities to maximize customer satisfaction or realize substantial cost reductions. Flexibility is essential in today's competitive environment, where customers are increasingly demanding a higher level of service, to suit their specific needs. Formalization facilitates the organization's ability to accommodate the routine requests of daily business operations. Flexibility allows the organization to be responsive to non-routine requests or take advantage of unexpected opportunities. Areas of flexibility are technology adoption; external alliance; and accommodation. The timely and accurate adoption of information technology encourages corporate responsiveness (Bowersox and Daugherty 1992).

Previous research states that leaders manage organizational strength effectively and efficiently to produce good results for all their leaders using different approaches to improve production conditions in an effective way (Ahmad and Ghayyur 2014). The results of previous research indicate that logistics leadership greatly affects the performance of logistic management (Bowersox and Daugherty 1992).

H2: the implementation of logistic leadership has the potential to improve the performance of logistics management

\section{Growth Mindset}

The human mindset (Mindset) has a tremendous effect on life. The right mindset will help reach the maximum potential, while the wrong mindset can lead to losses (Yeager et al. 2019). Every good and bad decision depends on how we perceive things. Two kinds of contradictory patterns of thought are the fixed mindset and growth mindset (Dweck 2008). The Fixed Mindset believes that character, intelligence, ability, and creativity are a permanent innate/talent that cannot be replaced, while the Growth Mindset believes that failure is not caused by incompetence, but is a challenge to develop and improve its abilities (Gupta and Govindarajan 2002). These two mindsets 
are very influential on success and failure in the fields of work, hobbies, personality and greatly affect a person's level of happiness (Gupta and Govindarajan 2002).

Someone who has a growth mindset is a person who is very eager to learn but does not get recognition from others because they think that intelligence and creativity, love and friendship, can be developed through serious effort and practice (Dweck 2008). The failure that exists does not limit their steps and efforts but is used as a lesson for success.

H3 : Growth Mindset strengthens the influence of logistics leadership in improving logistics management performance.

\section{Research Method}

This study belongs to exploratory and explorative research that aims to identify certain variables of a social phenomenon whose meaning needs to know and is carried out by exploring data from different perspectives to get better confirmation and understanding and analysis of the relationship between leadership and digital competency with logistics management. The sampling method in this study used census sampling techniques, namely all branches of Indah Logistic Indonesia Ltd. Data were obtained from the distribution of questionnaires distributed to respondents with a Likert scale 1-5. The collected data were then analyzed further in this study. The data were taken from 75 branches of Indah Logistic Ltd. in Indonesia. The data from the distribution of the questionnaires were then collected and analyzed using SEM PLS. The empirical models formed in this study are:

Figure 1. Empirical Model of the Research

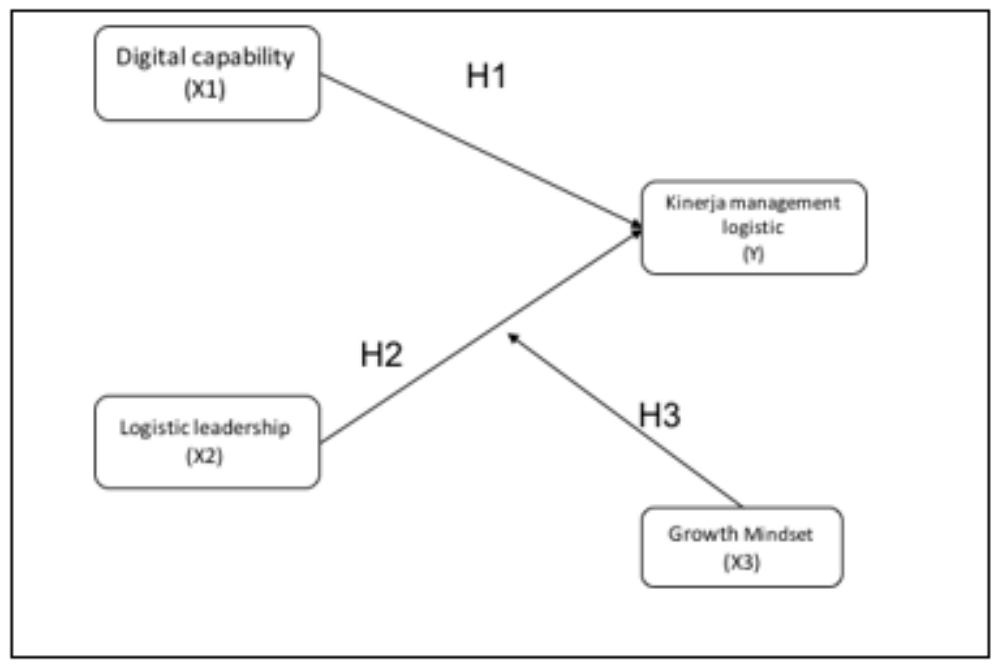

\section{Findings and Discussion} tabulations.

The results of data analysis using SEM PLS analysis software are shown in the following

Result of SEM PLS Analysis

\begin{tabular}{|c|c|c|c|c|}
\hline & $\begin{array}{l}\text { Original } \\
\text { Sample } \\
(O)\end{array}$ & $\begin{array}{l}\text { Sample } \\
\text { Mean } \\
(M)\end{array}$ & $\begin{array}{l}\text { Standard } \\
\text { Deviation } \\
\text { (STDEV) }\end{array}$ & $\begin{array}{l}T \quad \text { Statistics } \\
(|O / S T D E V|)\end{array}$ \\
\hline 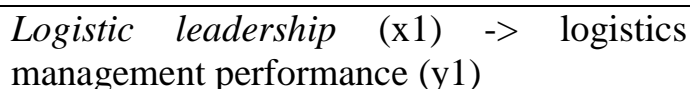 & 0,854 & 0,866 & 0,038 & 22,708 \\
\hline 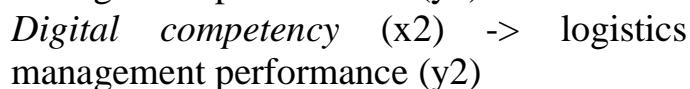 & 0,608 & 0,634 & 0,092 & 6,645 \\
\hline Moderating Effect 1 -> growth mindset $(\mathrm{y} 1)$ & 0,804 & 0,863 & 0,041 & 8,991 \\
\hline
\end{tabular}

The results of the SEM PLS analysis showed that the results of this study indicate that the better the implementation of logistics leadership, the better the logistics management performance 
will be. The more the CEO has good digital capabilities, the more it will affect the increase in logistics management performance. Growth mindset has the effect of strengthening logistics leadership in improving logistics management performance.

\section{The post-pandemic workforce, how leader increase the logistic management performance}

Based on the PLS test results in the table above, it is known that the original sample estimate was 0.854 . This value proves that logistics leadership has a positive effect on the performance of logistics management. From the proposed hypothesis test, it can be proven from the results of data processing that the calculated value is 22.708> t table (1.99), which means that the hypothesis (Ha) is accepted or Ho is rejected at a level of error of 5\%, two-tailed testing (two tailed). So, it can be concluded that there is a significant effect of logistics leadership on the performance of logistics management.

Employees are not only looking for financial benefits. Organizations that are able to inspire their employees to move forward and increase their capacity will cause employees to become engaged. Not a few employees have survived because they saw excellent examples of leadership in organizations. The future of every organization hinges on the development and retention of good leaders.

The leadership vision is developed by effective leadership because external and internal root causes for challenges and risks can be easily identified by them. Recognizing the leadership capabilities is a major challenge for companies and a prerequisite for sustaining organizational performance. The difference between superior performance and failure to perform can be attributed to organizational leadership and decision-making abilities at the senior management level. Thus, managerial and leadership abilities are the key to effectively managing existing human resources, maximizing HR potential and mastering remote worker management to become important assets in gaining a company's competitive advantage (Gosling et al. 2017).

\section{CEO Digital capability in the post-pandemic workforce: Bridging the uncertainty investing globally in resilience}

Based on the PLS test results in the table above, it is known that the original sample estimate results of 0.608 . This value proves that digital capability has a positive effect on the performance of logistics management. From the proposed hypothesis test, it can be proven from the results of data processing that the calculated value is 6.645> t table (1.99), which means that the hypothesis (Ha) is accepted or Ho is rejected at the level of error of 5\%, two-tailed testing (two tailed). So, it can be concluded that there is a significant effect of digital capability on the performance of logistics management.

CEOs who have digital fluency utilize technology in managing data, represent information creatively, solve problems, and design new products and ways of working and can influence job performance and career development in various professions. CEOs with digital capability are competent in their interaction process with technology which can be utilized in the workplace how to use some basic programs or applications but are those who are digitally fluent and have reached a level of proficiency that allows them to manage information, build ideas, and use technology to achieve strategic goals (Cenamor, Parida, and Wincent 2019). The digital era 4.0 requires digital capability and the strength of technological advances and opportunities for radical organizational change (Frederik 2019) but IT will not play much role if it is not followed by the ability of individuals to utilize technology in the service of organizational goals (Cenamor, Parida, and Wincent 2019).

The limitation of physical work involvement due to social distancing and health protocols that must be fulfilled causes human resources to be able to complete all their work by telecommuting, by utilizing digital devices and technology. Leaders must have the ability to move their human resources from distance, by increasing employee digital involvement which shows employee readiness, engagement and engagement eventhough they are separated (Choi and Sung 2020). The role of the CEO's capability in supervising and managing his HR digitally is the key to success in this era of remote workers and social distancing workforce. 


\section{From employee engage to socially distancing, the role of growth mindset of $\mathrm{CEO}$}

Based on the results of the PLS test in the table above, it is known that the original sample estimate results of 0.804 . This value proves that growth mindset has a significant positive effect in strengthening the relationship between logistics leadership on the performance of logistics management. From the proposed hypothesis test, it can be proven from the results of data processing that the count value is 8.991>t table (1.99), which means that the hypothesis (Ha) is accepted or Ho is rejected at a level of error of 5\%, two-tailed testing (two tailed). So, it can be concluded that growth mindset has the effect of strengthening logistics leadership in improving logistics management performance.

A number of challenges faced by organizational leaders in the post-pandemic era, from the point of view of strategy, innovation assets, mass markets, utilization of knowledge, capital resources, and organizational leaders must also change. The ability to compete in the new normal era of organizations must increasingly rely on the judgment, experience, skills and knowledge of the people they have. New knowledge must be assimilated and created, and innovation must also be encouraged. These organizations must also know how to compete in the market (Dess and Picken 2000). In the current era of globalization, employees are an important part of the organization and become the main determinants of success where employee performance is derived from employee energy, motivation and creativity. The potential possessed by employees needs to be utilized to achieve organizational goals. One of the most important factors of success in the success of an organization is effective leadership. Thus, such leadership development is very important for organizations (Yukl, G., \& Chavez 2002).

Effective leadership in business requires managers to demonstrate behavioral complexity, which is defined as the ability to act out cognitive complex strategies by playing multiple roles, even competing, in highly integrated and complementary ways. Research and literature focusing on leadership describes an effective leader as someone who: 1 . Serves the best interests of oneself and the organization 2. Continues to develop best practices and good behavior 3. Creates and seizes opportunities 4. Captures important information and takes action 5 Builds partnerships 6. Brings and promote change 7. Creates a vision and promote it (Dubey, Singh, and Gupta 2015).

As a leader, the CEO must have a mindset that is always growing, developing, and changing following global environment change. Leaders must have the intuition to see the future, see the opportunities and risks contained therein. Leaders who have a growth mindset are typical leaders who don't give up easily, tend to think positively about their abilities and are able to improve themselves by seeing their weaknesses in everything. Leaders with a growth mindset thinking believe that a person's ability is dynamic and can be improved with good effort. Leaders who have a growth mindset when experiencing failure will try again and learn from their mistakes for their failures. Their motivation will emerge because the level of confidence in their abilities always leads to the positive side. Leaders who have a growth mindset will focus on the learning goals they will get in the process of achieving goals.

Assessing the inner model is evaluating the relationship between latent constructs as hypothesized, where the relationship of each construct is measured by 2 latent constructs. As illustrated in the results of the following R-square value as in Table 2.

Table 2. R-SQUARE $\left(\mathbf{R}^{2}\right)$ VALUE

\begin{tabular}{lr}
\hline & R Square \\
\hline Logistics Management Performance & 0,666 \\
\hline
\end{tabular}

Based on the $\mathrm{R}$ square value, it can be seen that the variation in logistic management performance can be explained by digital capability, logistic leadership and growth mindset by $66.6 \%$. The remaining $33.4 \%$ is explained by variations in other variables which were not included in the model.

\section{CONCLUSION}

The Covid-19 pandemic has made many changes to the situation and policies in all fields today. These changes must be carried out comprehensively in every pattern and manner of life, 
whether at the individual, family, small community, corporate or state policy levels. Companies or corporations are required to immediately adapt to very high uncertainty. The new phase that will be faced at this time is called new normal. The condition is from the impact of the global crisis where all sectors in the world are required to continue to live side by side with a new order and way of life in facing the pandemic.

The first change is a mental attitude which requires feeling comfortable with existing discomforts, getting used to unusual things, preparing yourself for unwanted changes and adapting to existing changes. The current situation is certainly very uncomfortable but the ability of a leader to help his human resources through this inconvenience will bring about a change into a new culture in the organization by using imagination, way of thinking and point of view to make things that didn't exist before, and what were not used to be normal or New Normal. Mindset has a tremendous influence to reach the maximum potential while the wrong mindset can destroy lives. Everything in life depends on our perspective.

In the new normal, our mindset tells us that we are going to enter a new world. Leaders with a fixed mindset will think that failure received due to new normal or pandemic conditions is failure due to their inability and wrong circumstances to validate themselves. However, leaders with new normal growth are how to develop themselves to learn something new and develop their potential. Leaders with a growth mindset want to develop themselves and are not afraid of failure, because success for them is to be smarter. Leaders with a growth mindset will be happy to accept criticism from others as an effort to expand their knowledge.

The limitation of this study is that it has not yet been juxtaposed with secondary data for discussion. Cargo transportation involves a lot of interaction between implementing parties who have different characteristics and roles in cargo services, including airports that usually provide / lease warehousing facilities to be managed by other parties, flight operators implementing cargo transportation, cargo handling that carries out loading and unloading of cargo from / to aircraft, duties excise as a supervisor / inspector of goods, as well as an expedition as an organizer of cargo shipments from the airport of origin to the destination airport (Jorgenson and $\mathrm{Vu}$ 2016). An efficient cargo transportation system with minimum transportation costs and production costs of goods takes into account Indonesia's geographical characteristics and transportation modes. One of the advantages of air transportation is the type and carrying capacity of cargo aircraft that have high cruise flexibility, and allow delivery to areas that are not yet covered by other modes of transportation by using pioneer flights (Yarlina 2013).

\section{REFERENCES}

Ahmad, Mushtaq, and Muhammad Ghayyur. 2014. "How Value Vased Leadership Influences Logistic Support Services and Employees Satisfaction?" International Review of Management and Business Research 3(1): 55-67.

Balsmeier, Benjamin, and Martin Woerter. 2019. "Is This Time Different? How Digitalization Influences Job Creation and Destruction.” Research Policy 48(8): 103765.

Bass, B. M. 1985. Collier Macmillan. Leadership and Performance beyond Expectations

.Bowersox, D. J., \& Daugherty, P. J. 1995. "Logistics Paradigms: The Impact of Information Technology." Journal of Business logistics, 16(1): 65.

Bowersox, Donald J. 2000. Manajemen Logistik Jilid 1 Dan 2, Terjemahan : A. Hasymi Ali. Jilid 1 da. Bumi Aksara, Jakarta.

Bowersox, Donald J., and Patricia J. Daugherty. 1992. "Logistics Leadership - Logistics Organizations of the Future." Logistics Information Management 5(1).

C. Rutner, Stephen M., and C.John Langley. 2006. "Article Information: Logistics Value:Definition, Process and Measurement." The International Journal of Logistics of Logistics Management 11(2): 73-82.

Cenamor, Javier, Vinit Parida, and Joakim Wincent. 2019. "How Entrepreneurial SMEs Compete through Digital Platforms: The Roles of Digital Platform Capability, Network Capability and Ambidexterity." Journal of Business Research 100(April): 196-206.

Chen, Jiajia, and Jiajia Chen. 2020. "Feasibility of Telecommuting by Improving Operations SelfManagement in Air Export Freight Forwarding." 
Choi, Dae Soo, and Chang Soo Sung. 2020. "How Does Technology Startups Increase Innovative Performance? The Study of Technology Startups on Innovation Focusing on Employment Change in Korea."

Darkow, Inga Lena, Bernadette Foerster, and Heiko A. Von Der Gracht. 2015. "Sustainability in Food Service Supply Chains: Future Expectations from European Industry Experts toward the Environmental Perspective." Supply Chain Management 20(2): 163-78.

Dess, Gregory G, and Joseph C Picken. 2000. "Changing Roles: Leadership in the 21st Century." Organizational Dynamics 28(3): 18-34.

Dubey, Rameshwar, Tripti Singh, and Omprakash K. Gupta. 2015. "Impact of Agility, Adaptability and Alignment on Humanitarian Logistics Performance: Mediating Effect of Leadership." Global Business Review 16(5): 812-31.

Dweck, C. S. 2008. "Executive Book Summary Mindset: The New Psychology of Success." Mindset the New Psycology of Success.

Frederik, Milan. 2019. "What One Needs to Master Today 's Organisational Challenges."

Gosling, Jonathan, Fu Jia, Yu Gong, and Steve Brown. 2017. "The Role of Supply Chain Leadership in the Learning of Sustainable Practice: Toward an Integrated Framework." Journal of Cleaner Production 140: 239-50.

Griffin, Romonda P. 2020. "QUALITATIVE NARRATIVE INQUIRY EXPLORING LEADERSHIP STRATEGIES Doctor of Management in Organizational Leadership University of Phoenix."

Gupta, Anil K., and Vijay Govindarajan. 2002. "Cultivating of Global Mindset." Academy of Management Executive 16(1): 116-26.

Hamdam, Y. 2020. "Airport Cargo Logistics and Economic Outcome of Supply Chain: An Empirical Analysis." Int. J Sup. Chain. Mgt 9(1): 256.

Jorgenson, Dale W., and Khuong M. Vu. 2016. "The ICT Revolution, World Economic Growth, and Policy Issues." Telecommunications Policy 40(5): 383-97.

Lambert, D., Stock, J. R., \& Ellram, L. M. 1998. Fundamentals of Logistics Management. McGraw-Hill/Irwin.

Mena, C., Christopher, M., \& Van Hoek, R. 2014. "Leading Procurement Strategy: Driving Value through the Supply Chain." Kogan Page Publishers. 1.

Mentzer, John T., Theodore P. Stank, and Terry L. Esper. 2008. "Supply Chain Management and Its Relationship To Logistics, Marketing, Production, and Operations Management." Journal of Business Logistics 29(1): 31-46.

Mogaka, Conrad, and Wycliffe Arani. 2020. "Logistics Strategy as a Competitive Tool for Firm Performance: The Moderating Effect of Customer Service Effectiveness." Journal of Sustainable Development of Transport and Logistics 5(1): 56-65.

Nwankpa, Joseph K., and Yaman Roumani. 2016. "IT Capability and Digital Transformation: A Firm Performance Perspective." 2016 International Conference on Information Systems, ICIS 2016: 1-16.

Pratiwi, Ratih, Sri Hartono, Editya Nurdiana, and Dasmadi Dasmadi. 2020. "Digital Capability and Communication Skill for Empowering Self-Efficacy in Tourism Industry." 123(Icamer 2019): 126-29.

Pujawan, I Nyoman. 2005. Supply Chain Management. Surabaya.: Guna Widya,.

Quick, James Campbell, and Debra L. Nelson. 2008. "Leadership Development: On the Cutting Edge." Consulting Psychology Journal 60(4): 293-97.

Rauter, Romana, Dietfried Globocnik, Elke Perl-Vorbach, and Rupert J. Baumgartner. 2019. "Open Innovation and Its Effects on Economic and Sustainability Innovation Performance." Journal of Innovation and Knowledge 4(4): 226-33. https://doi.org/10.1016/j.jik.2018.03.004.

Ruben, Brent D. 2019. "An Overview of the Leadership Competency Framework." Competencies for Effective Leadership: 19-28.

Sadowski, Adam, Katarzyna Wąsowska, and Iwo Nowak. 2020. "Logistics Development in European Countries: The Case of Poland." European Research Studies Journal XXIII(Issue 2): 500-514. 
Safonov Yu. M., Borshch V. I. 2017. "Intellectual Leader and His Role in the Modern Management System." Internationalization and Diversity in Higher Education 1(1): 62-94.

Saragih, Nova Indah, Verani Hartati, and Muchammad Fauzi. 2020. "Tren, Tantangan, Dan Perspektif Dalam Sistem Logistik Pada Masa Dan Pasca (New Normal) Pandemik Covid-19 Di Indonesia." Jurnal Rekayasa Sistem Industri 9(2): 77-86.

Tan, Yongtao, J. Jorge Ochoa, Craig Langston, and Liyin Shen. 2015. "An Empirical Study on the Relationship between Sustainability Performance and Business Competitiveness of International Construction Contractors." Journal of Cleaner Production 93: 273-78. http://dx.doi.org/10.1016/j.jclepro.2015.01.034.

Ul-Hameed, Waseem et al. 2019. "Remedies of Low Performance among Pakistani E-Logistic Companies: The Role of Firm's IT Capability and Information Communication Technology (ICT)." Uncertain Supply Chain Management 7(2): 369-80.

Yarlina, Lita. 2013. "Jurnal Perhubungan Udara Pangsa Pasar ( Market Share ) Logistik / Kargo Oleh Perusahaan Jasa Angkutan Udara Yang Beroperasi Di Bandar Udara Internasional Sepinggan Balikpapan Logistic / Cargo Market Share of Airline in Sepinggan International Airport Bali." : 112-26.

Yeager, David S. et al. 2019. "A National Experiment Reveals Where a Growth Mindset Improves Achievement." Nature 573(7774): 364-69. http://dx.doi.org/10.1038/s41586-019-1466-y.

Yukl, G., \& Chavez, C. 2002. "Influence Tactics and Leader Effectiveness." Leadership: 39-165. 